\title{
Effects of Prednisolone and Dexamethasone in Vivo and in Vitro: Studies of Insulin Binding, Deoxyglucose Uptake and Glucose Oxidation in Rat Adipocytes
}

\author{
R. De Pirro', A. Green, M. Yung-Chin Kao, and J. M. Olefsky \\ Department of Medicine, University of Colorado Health Sciences Center, Division of Endocrinology, Denver, CO 80262, USA
}

\begin{abstract}
Summary. We have studied the effects of dexamethasone and prednisolone in vitro and in vivo on insulin binding, deoxyglucose uptake and glucose oxidation in rat adipocytes. In the studies in vivo, rats were treated for $22 \mathrm{~h}$ with dexamethasone $(30 \mu \mathrm{g} / \mathrm{kg})$ or prednisolone $(200 \mu \mathrm{g} / \mathrm{kg})$. Following sacrifice, adipocytes were prepared and the results demonstrated that cells from prednisolone treated rats showed a $17 \%$ increase in insulin binding and increased rates of basal and insulin stimulated deoxyglucose uptake and glucose oxidation. Conversely, dexamethasone administration resulted in a $22 \%$ decrease in insulin binding, and decreased rates of deoxyglucose uptake and glucose oxidation by the cells. Thus, prednisolone and dexamethasone had opposite effects in vivo. In contrast to the opposite effects of the two glucocorticoids in vivo, dexamethasone and prednisolone (each at a concentration of $1 \mu \mathrm{mol} / \mathrm{l}) \mathrm{had}$ similar effects on adipocytes in vitro. Incubation of adipocytes with the steroids did not alter insulin binding, while both agents led to a comparable decrease in the rates of basal and insulin stimulated deoxyglucose uptake and glucose oxidation. Thus, dexamethasone and prednisolone have opposite effects on adipocyte glucose metabolism in vivo but have similar effects in vitro.
\end{abstract}

Key words: Insulin, adipocytes, prednisolone, dexamethasone, insulin binding, deoxyglucose transport, glucose oxidation

Insulin resistance is a well documented consequence of glucocorticoid administration both in man $[1,2]$ and rats $[3,4]$. One cause of this insulin resistance is the well known effect of these drugs to inhibit tissue

\footnotetext{
' Present address: 2 Clinica Medica, Policlinico Umberto 1, I-00145 Roma, Italy
}

glucose uptake and metabolism [5]. In addition to their effects on glucose metabolism, administration of glucocorticoids in vivo may also impair insulin binding to target cells, and this could provide another cause for glucocorticoid-induced insulin resistance. The results of several studies support this hypothesis. Thus, it has been demonstrated that treatment of rats with dexamethasone decreases the insulin binding capacity of hepatocytes and adipocytes $[6,7]$. However, Beck-Nielsen et al. [8] have demonstrated that administration of prednisone in man produces an increase in the insulin binding capacity of circulating monocytes. These apparently conflicting results raise the possibility that different glucocorticoids can produce divergent effects on both insulin binding and glucose metabolism. In order to test this hypothesis we have studied the effects of prednisolone and dexamethasone on insulin binding and insulin action on rat adipocytes both in vivo and in vitro.

\section{Materials and Methods}

\section{Materials}

Porcine highly-purified insulin was generously supplied by Dr. Ronald Chance of Eli Lilly, Indianapolis. Bovine serum albumin (fraction V) was purchased from Armour, Phoenix, Arizona; col-

Table 1. Plasma glucose, non-esterified fatty acid and insulin concentration in rats treated with dexamethasone or prednisolone for $22 \mathrm{~h}$

\begin{tabular}{lccc}
\hline Plasma & Control & \multicolumn{2}{c}{ Dexamethasone Prednisolone } \\
\hline Glucose $(\mathrm{mmol} / \mathrm{l})$ & $7.9 \pm 0.2(7)$ & $8.0 \pm 0.1(7)$ & $7.6 \pm 0.2(6)$ \\
NEFA $(\mu \mathrm{mol} / \mathrm{l})$ & $176 \pm 21(7)$ & $274 \pm 24^{\mathrm{c}}(7)$ & $250 \pm 34^{\mathrm{b}}(5)$ \\
Insulin $(\mathrm{mU} / \mathrm{l})$ & $16 \pm 2(7)$ & $21 \pm 4^{\mathrm{e}}(7)$ & $11 \pm 1^{\mathrm{a}}(6)$ \\
\hline
\end{tabular}

Results are means \pm SEM for number of rats shown in parentheses. The statistical significance of differences between the treated groups and controls are indicated by ${ }^{\mathrm{a}}(p<0.05),{ }^{\mathrm{b}}(p<0.01)$ and ${ }^{c}(p<0.001)$ 
lagenase from Worthington Biochemicals, Freehold, New Jersey; $\left[{ }^{125} \mathrm{I}\right] \mathrm{Na}, 2$-deoxy-[1- $\left.{ }^{3} \mathrm{H}\right]$-glucose $(16.1 \mathrm{Ci} / \mathrm{mmol}), \mathrm{L}-\left[1-{ }^{3} \mathrm{H}[-\mathrm{glu}-\right.$ cose $(10.7 \mathrm{Ci} / \mathrm{mmol}),\left[1-{ }^{14} \mathrm{C}\right]$-glucose $(61 \mathrm{Ci} / \mathrm{mmol})$ from New England Nuclear, Cambridge, Massachusetts; dexamethasone and prednisolone from Sigma, St. Louis; silicone oil (6428-R15) from Arthur H. Thomas, Philadelphia.

\begin{abstract}
Animals
Male Sprague-Dawley rats $(160-170 \mathrm{~g})$ were used for all experiments. Animals were injected SC three times (at 1500, 2300 and $0700 \mathrm{~h})$ with saline $(0.154 \mathrm{~mol} / \mathrm{l})$, dexamethasone $(30 \mu \mathrm{g} / \mathrm{kg})$ or prednisolone $(200 \mu \mathrm{g} / \mathrm{kg})$ and then stunned by a blow to the head and decapitated at $1300 \mathrm{~h}$. Thus, each rat was killed $6 \mathrm{~h}$ after the last injection ( $22 \mathrm{~h}$ after the first injection). The injection volume was $0.4 \mathrm{ml}$ and steroids were freshly prepared from stock solutions in ethanol by drying the desired amount under nitrogen and resuspending in saline. All rats had free access to standard rat chow and water. No weight differences were found between any of the groups.
\end{abstract}

\section{Preparation of Isolated Adipocytes}

Isolated fat cells were prepared from epididymal fat pads by shaking at $37^{\circ} \mathrm{C}$ for $60 \mathrm{~min}$ in Krebs-Ringer bicarbonate buffer (pH 7.4) containing collagenase $(3 \mathrm{mg} / \mathrm{ml})$ and bovine serum albumin (BSA) $(40 \mathrm{mg} / \mathrm{ml})$ according to the method of Rodbell [9]. Cells were filtered through $250 \mu \mathrm{M}$ nylon mesh, centrifuged at $400 \mathrm{rev} /$ min for $4 \mathrm{~min}$ and washed twice in buffer. Adipocyte counts were performed according to a modification of method III of Hirsch and Gallian [10] in which the cells were fixed in $2 \%$ osmium tetroxide in $0.05 \mathrm{~mol} / \mathrm{l}$ collidine buffer (made up to physsiological osmolality with saline) for $24 \mathrm{~h}$ at $37^{\circ} \mathrm{C}$ and then taken up in a known volume of $0.154 \mathrm{mmol} / 1 \mathrm{NaCl}$ for counting with a Coulter Counter Model ZB.

\section{Iodination of Insulin}

$\left[{ }^{125} \mathrm{I}\right]$ insulin was prepared at a specific activity of $170-190 \mu \mathrm{Ci} / \mu \mathrm{g}$ according to a modification [11] of the method of Hunter and Greenwood [12].

\section{Binding Studies}

Isolated fat cells were suspended in a buffer containing $35 \mathrm{mmol} / \mathrm{l}$ Tris, $120 \mathrm{mmol} / 1 \mathrm{NaCl}, 1.2 \mathrm{mmol} / 1 \mathrm{MgSO}_{4}, 5 \mathrm{mmol} / 1 \mathrm{KCl}$, $10 \mathrm{mmol} / \mathrm{l}$ glucose, $2 \mathrm{mmol} / 1 \mathrm{CaCl}_{2}, 24 \mathrm{mmol} / 1 \mathrm{Na}$ acetate and $10 \mathrm{mg} / \mathrm{ml} \mathrm{BSA}, \mathrm{pH} 7.6$, and incubated with $\left[{ }^{125} \mathrm{I}\right]$ insulin and unlabelled insulin in plastic flasks in a $24^{\circ} \mathrm{C}$ shaking water bath as previously described [13]. Optimal steady-state binding conditions are achieved at $24^{\circ} \mathrm{C}$ after $60 \mathrm{~min}$ of incubation. The incubations were terminated by removing $200 \mu \mathrm{l}$ aliquots from the cell suspension and rapidly centrifuging the cells in plastic microtubes to which $100 \mu \mathrm{l}$ silicone oil had been added [14]. The cells were then removed and the radioactivity determined. All studies were carried out in triplicate.

\section{2-Deoxyglucose Uptake}

These studies were performed using the same cell centrifugation technique as described for the binding studies, and the details of this method have been previously reported $[15,16]$. Unless otherwise stated, isolated adipocytes were incubated with 2-deoxy[1- $\left.{ }^{3} \mathrm{H}\right]-\mathrm{D}$-glucose at a concentration of $0.125 \mathrm{mmol} / 1$ in KrebsRinger bicarbonate ( $\mathrm{pH} 7.4)$ containing BSA $(10 \mathrm{mg} / \mathrm{ml})$ at $24^{\circ} \mathrm{C}$.
This assay measures the total uptake of the radiolabelled 2-deoxyglucose and is based on the principle that, although 2-deoxyglucose can be phosphorylated like $\mathrm{D}$-glucose, it cannot be further metabolised [17]. The assay was terminated at the end of $3 \mathrm{~min}$ by transferring $200 \mu \mathrm{I}$ aliquots from the assay mixture to plastic microtubes containing $100 \mu \mathrm{l}$ silicone oil. The tubes were centrifuged for $30 \mathrm{~s}$ in a Beckman microfuge, and the assay was considered terminated when centrifugation begins. In experiments in which the stimulatory effect of insulin on uptake was measured, the cells were preincubated with insulin for $60 \mathrm{~min}$ at $24^{\circ} \mathrm{C}$. The amount of sugar trapped in the extracellular water space of the cell layers was determined using $\mathrm{L}-\left[1-{ }^{3} \mathrm{H}\right]$-glucose, and was $0.033 \pm 0.001 \%$ (mean \pm SEM)

\section{Glucose Oxidation}

The ability of adipocytes to oxidize glucose was determined according to the method of Rodbell [9]. Adipocytes were incubated at $37^{\circ} \mathrm{C}$ with $\left[1-{ }^{14} \mathrm{C}\right]$-glucose $(2 \mathrm{mmol} / \mathrm{l})$ in Krebs-Ringer bicarbonate buffer ( $\mathrm{pH} 7.4$ ) containing BSA $(40 \mathrm{mg} / \mathrm{ml})$. After $1 \mathrm{~h}$ of incubation the generated ${ }^{14} \mathrm{CO}_{2}$ was collected and counted in a liquid scintillation counter.

\section{Analytical Methods}

Plasma glucose was determined by the glucose oxidase method using a Beckman glucose analyser. Plasma insulin was determined by the double antibody radioimmunoassay [18], and non-esterified fatty acid (NEFA) by the method of Chlouverakis and Hojnicki [19].

\section{Statistical Analysis}

Results are presented as mean \pm SEM. Analysis of variance was used to test for significant changes.

\section{Results}

\section{Studies in Vivo}

The effects of $22 \mathrm{~h}$ dexamethasone or prednisolone treatment on plasma glucose, NEFA and insulin concentrations are presented in Table 1 . As can be seen, dexamethasone treatment led to an increase, whilst prednisolone led to a decrease in plasma insulin concentration. Neither steroid had any statistically significant effect on plasma glucose concentration, whereas plasma NEFA concentrations were elevated in both treatment groups. It should be noted that food intake and body weight were the same in controls and both experimental groups over the treatment period.

Insulin Binding: Prednisolone and dexamethasone had opposite effects on the ability of adipocytes to bind insulin. Cells from control rats bound $2.09 \pm$ $0.09 \%$ of a tracer concentration $(0.2 \mathrm{ng} / \mathrm{ml})$ of insulin per $2 \times 10^{5}$ cells. Administration of prednisolone resulted in an increase to $2.41 \pm 0.15 \%$ per $2 \times 10^{5}$ 
cells, whilst dexamethasone led to a decrease to 1.64 $\pm 0.10 \%$ per $2 \times 10^{5}$ cells in binding. The amount of buffer insulin degraded during the binding assay was always $<10 \%$, and no differences were observed between the amount of insulin degraded by adipocytes from control, dexamethasone or prednisolone treated animals.

Insulin binding was studied over a range of insulin concentrations and the resulting competition curves are shown in Figure 1a. The shapes of these curves were comparable and treatment with the different glucocorticoids led to opposite effects on insulin binding at each insulin concentration. Scatchard plots of these insulin binding data are shown in Fig. $1 \mathrm{~b}$. The curves are generally parallel, whilst the intercepts or the abscissa are different, suggesting that the alterations in insulin binding are due to changes in the number of insulin receptors per cell, rather than to changes in affinity.

2-Deoxyglucose Uptake: The effect of insulin on 2deoxyglucose uptake by adipocytes from control and glucocorticoid treated rats is shown in Fig. 2. It can be seen that dexamethasone administration resulted in decreased rates of uptake at all insulin concentrations. Prednisolone produced the opposite effect; that is uptake was increased at all insulin concentrations.

Glucose Oxidation: The effects of administration of the glucocorticoids on glucose oxidation were similar to those on 2-deoxyglucose uptake (Fig. 3). Again, the effect of prednisolone was opposite to that of dexamethasone. Thus, basal and insulin stimulated glucose oxidation were increased by prednisolone, but decreased by dexamethasone.

\section{Studies in Vitro}

Insulin Binding: Adipocytes were incubated with dexamethasone or prednisolone $(1 \mu \mathrm{mol} / \mathrm{l})$ for 2,4 , or $6 \mathrm{~h}$. Neither of the steroids altered the insulin binding capacity of the cells (results not shown).

Glucose Oxidation: Figure 4 shows the effect of insulin on glucose oxidation by adipocytes which had been incubated with the glucocorticoids. It can be seen that both steroids decreased the rates of oxidation in the absence of insulin, and at all insulin concentrations tested.

2-Deoxyglucose Uptake: Dexamethasone and prednisolone produced similar effects in vitro on 2-deoxyglucose uptake to those described above for glucose oxidation. Thus, both glucocorticoids decreased the rates of basal and insulin stimulated 2-deoxyglucose uptake by the cells (data not shown).
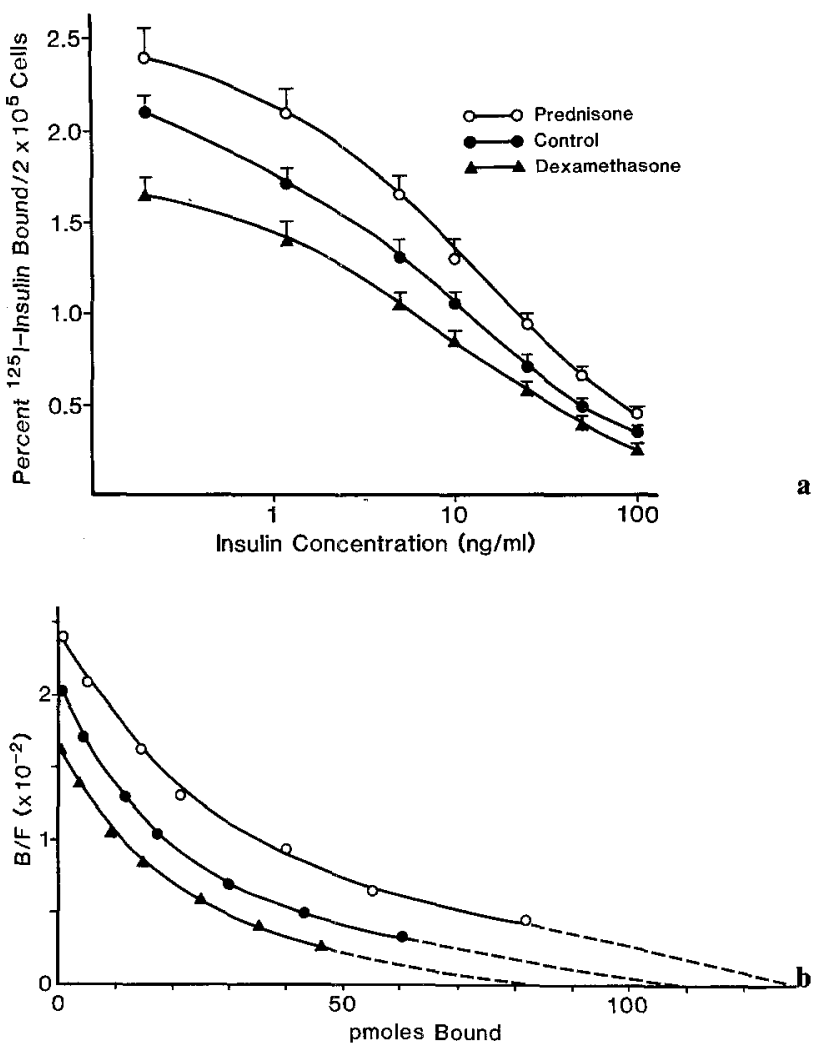

Fig. 1. Effects of prednisolone and dexamethasone on insulin binding to adipocytes. a Ability of adipocytes from control ( $)$, prednisolone $(O)$ and dexamethasone $(\boldsymbol{\Delta})$ treated rats to specifically bind $\left[{ }^{125} \mathrm{I}\right]$ insulin. Data represent mean values of seven rats from each group. b Scatchard plots of the insulin binding data in (a) above

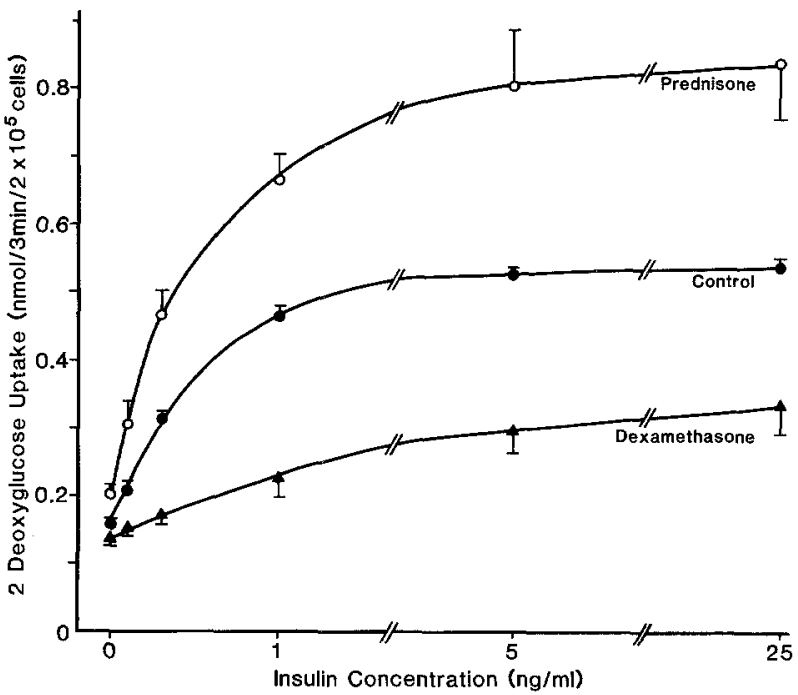

Fig. 2. 2-Deoxyglucose uptake by adipocytes from control (•), prednisolone $(0)$ and dexamethasone $(\mathbf{\Delta})$ treated rats. Data represent the mean \pm SEM of three rats from each group. Statistical analysis showed that control versus prednisolone and control versus dexamethasone was different at each insulin concentration tested $(\mathrm{p}<0.001)$ 


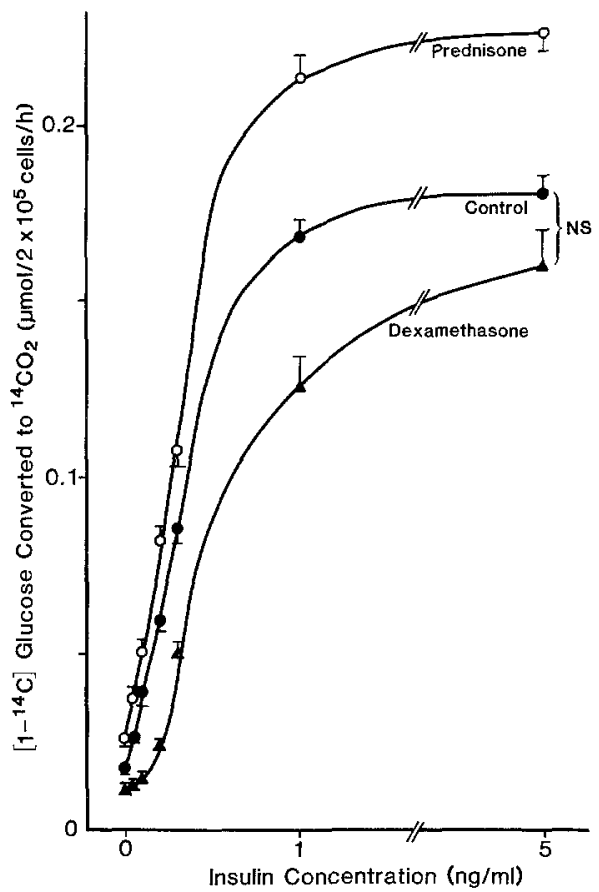

Fig. 3. $\left[1-{ }^{14} \mathrm{C}\right]$ glucose oxidation by adipocytes from control $(\bullet)$, prednisolone $(O)$ and dexamethasone $(\boldsymbol{\Delta})$ treated rats. Data represent the mean \pm SEM of four rats from each group. Statistical analysis showed that control versus prednisolone and control versus dexamethasone was significantly different $(\mathrm{p}<0.001)$ at each concentration of insulin tested, unless otherwise indicated on the figure

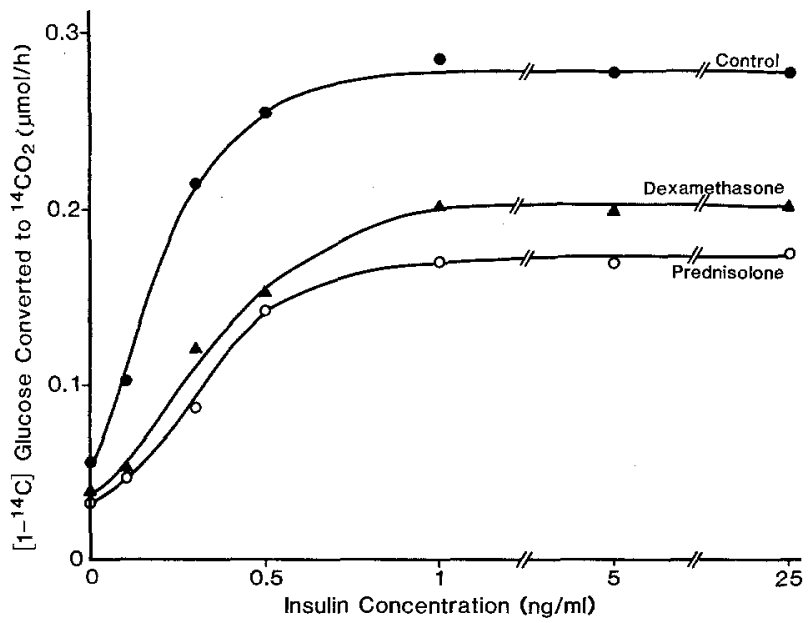

Fig. 4. Effect of prednisolone and dexamethasone on $\left[1-{ }^{14} \mathrm{C}\right] \mathrm{glu}-$ cose oxidation by adipocytes. Adipocytes (approximately $2 \times 10^{5}$ ) were incubated without steroid (๑), with $1 \mu \mathrm{mol} / \mathrm{l}$ prednisolone (O) or $1 \mu \mathrm{mol} / \mathrm{l}$ dexamethasone (A) for $3 \mathrm{~h}$ at $37^{\circ} \mathrm{C}$. Insulin was then added at the concentrations indicated, and oxidation measured over the next hour as described in Materials and Methods. Data represent the mean \pm SEM of five separate experiments. Statistical analysis showed that control versus prednisolone and control versus dexamethasone was significantly different at each insulin concentration tested $(\mathrm{p}<0.01)$

\section{Discussion}

The results reported in this paper demonstrate that administration of dexamethasone and prednisolone have markedly differing effects on insulin binding and on the ability of insulin to stimulate glucose metabolism in adipocytes. Cells from rats treated with dexamethasone showed a decreased capacity to bind insulin, and Scatchard analysis suggested that this was due to a decreased number of insulin receptors. These cells also showed decreased rates of basal and insulin stimulated deoxyglucose uptake and glucose oxidation. Administration of prednisolone produced opposite changes to dexamethasone; that is binding was increased and rates of basal and insulin stimulated deoxyglucose uptake and glucose oxidation were also increased. In contrast to these opposite effects of the two steroids in vivo, when incubated with adipocytes in vitro, prednisolone and dexamethasone had similar effects. Thus, insulin binding was not altered, while rates of basal and insulin stimulated deoxyglucose uptake and glucose oxidation were decreased by both steroids.

The finding that administration of dexamethasone decreases insulin binding to adipocytes is in agreement with previous reports. Thus, it has been demonstrated that dexamethasone treatment of rats reduces insulin binding to adipocytes and hepatocytes [6] and liver plasma membranes [7]. In addition, the finding of increased insulin binding to adipocytes from rats treated with prednisolone is consistent with the report of Beck-Nielsen et al. [8] who demonstrated that administration of prednisone (which is rapidly converted to prednisolone) in man increases insulin binding to circulating monocytes. Table 1 shows that dexamethasone treatment led to an increase, whereas prednisolone led to a decrease in the plasma insulin level. Since it is well-known that the circulating insulin level can inversely regulate cellular insulin receptor number [20], it is possible that the changes in vivo in insulin receptors were secondary to the alterations in plasma insulin concentration. However, it is also possible that changes in receptor number led to the differences in insulin levels, and, at any rate, it is difficult to assign sequential cause and effect relationships in this type of in vivo study.

It is generally accepted that glucocorticoid administration decreases peripheral glucose utilization (for review see [5]). The finding that dexamethasone decreases basal and insulin stimulated glucose transport and oxidation is therefore consistent with this view. Furthermore, this effect of dexamethasone administration on adipocyte metabolism has been described previously [15]. However, we have demonstrated that acute administration of prednisolone in vivo has the opposite effect, suggesting that this com- 
pound may have the seemingly paradoxical effect of enhancing overall glucose disposal in vivo. Indeed, some support for this notion can be found in the literature. Thus, Issekutz and co-workers studied the metabolic clearance rate of glucose in vivo by radiolabeled glucose infusion techniques in dogs [21, 22]. Their results indicate that methylprednisolone treatment leads to a $70 \%$ increase in overall glucose uptake.

When incubated with adipocytes in vitro, both dexamethasone and prednisolone decreased basal and insulin stimulated glucose transport and oxidation. However, both steroids were without effect on insulin binding to cells. Thus, it seems that the increase in glucose utilization by adipocytes isolated from rats treated with prednisolone is not a direct effect of the steroid on the cells, but must be mediated by some secondary factor resulting from prednisolone administration in vivo. Additionally, the potency of this effect must be significant, since it over-rides the direct action of prednisolone to decrease glucose transport and oxidation in vitro. Although it is possible that different doses of these glucocorticoids or different lengths of administration might lead to other comparative effects, it is clear that under these experimental conditions prednisolone and dexamethasone have opposite effects. Whatever the mechanism of these effects, it is important to note that our results show that chemically similar glucocorticoid preparations can lead to divergent metabolic actions.

Impaired glucose tolerance following glucocorticoid therapy is a well documented phenomenon [23] and prednisolone also causes this effect [24]. Theoretically, this decrease in glucose tolerance can be due to a combination of decreased glucose utilization and of increased hepatic glucose production [5]. For glucocorticoids which exert their effects as dexamethasone does, it is probable that both decreased glucose uptake and increased hepatic glucose production are operative factors. On the other hand, our results suggest that prednisolone increases peripheral glucose utilization, indicating that increased hepatic glucose production is the mechanism whereby prednisolone causes intolerance.

\section{References}

1. Conn JW, Fajans SS (1956) Influence of adrenal cortical steroids on carbohydrate metabolism in man. Metabolism 5: 114-127

2. McKiddie MT, Jasani MK, Buchanan KD, Boyle JA, Buchanan WW (1968) The relationship between glucose tolerance, plasma insulin and corticosteroid therapy in patients with rheumatoid arthritis. Metabolism 17: 730-739

3. Bates RW, Garrison MM (1967) Quantitative study of the diabetogenic action of ACTH and growth hormone in partially pancreatectomized rats. Endocrinology 81: 527-534

4. Bates RW, Garrison MM (1971) Studies in $80 \%$ pancreatectomized rats of the synergistic interaction of growth hormone, ACTH and the glucocorticoids (corticosterone, cortisol, pred- nisone and dexamethasone) as diabetogenic agents. Endocrinology 88: 1429-1436

5. Baxter JD, Forsham RH (1972) Tissue effects of glucocorticoids. Am J Med 53: 573-589

6. Olefsky JM, Johnson J, Liu F, Jen P, Reaven GM (1975) The effects of acute and chronic dexamethasone administration on insulin binding to isolated rat hepatocytes and adipocytes. Metabolism 24: 517-527

7. Kahn CR, Goldfine ID, Neville DM, DeMeyts P (1978) Alterations in insulin binding induced by changes in vivo in the levels of glucocorticoids and growth hormone. Endocrinology 103: 1054-1066

8. Beck-Nielsen H, De Pirro R, Pedersen O (1980) Prednisone increases the number of insulin receptors on monocytes from normal subjects. J Clin Endocrinol Metab 50: 1-4

9. Rodbell M (1964) Metabolism of isolated fat cells: 1. Effects of hormones on glucose metabolism and lipolysis. J Biol Chem 239: $375-380$

10. Hirsch J, Gallian E (1968) Methods for the determination of adipose cell size in man and animals. J Lipid Res 9: 110-119

11. Freychet P, Roth J, Neville DM (1971) Monoiodoinsulin: demonstration of its biological activity and binding to fat cells and liver membranes. Biochem Biophys Res Commun 43: $400-408$

12. Hunter WM, Greenwood FC (1962) Preparation of iodine131 labelled human growth hormone of high specific activity. Nature 194: 495-496

13. Olefsky JM, Jen P, Reaven GM (1974) Insulin binding to isolated human adipocytes. Diabetes 23: 565-571

14. Gammeltoft S, Gliemann J (1973) Binding and degradation of ${ }^{125} \mathrm{I}$-labelled insulin by isolated rat fat cells. Biochim Biophys Acta 320: 16-32

15. Olefsky JM (1975) Effect of dexamethasone on insulin binding, glucose transport and glucose oxidation of isolated rat adipocytes. J Clin Invest 56: 1499-1508

16. Olefsky JM (1978) Mechanisms of the ability of insulin to activate the glucose-transport system in rat adipocytes. Biochem J 172: 137-145

17. Chang K-J, Cautrecasas P (1974) Adenosine triphosphatedependent inhibition of insulin-stimulated glucose transport in fat cells: Possible role of membrane phosphorylation. J Biol Chem 249: 3170-3180

18. Desbuquois B, Aurbach GH (1971) Use of polyethylene glycol to separate free and antibody-bound peptide hormones in radioimmunoassays. J Clin Endocrinol Metab 33: 732-738

19. Chlouverakis C, Hojnicki D (1974) A modified radiochemical assay for serum free fatty acid determination. Clin Chim Acta 54: $91-94$

20. Gavin JR III, Roth J, Neville DM Jr, DeMeyts P, Buell DN (1974) Insulin-dependent regulation of insulin receptor concentrations: A direct demonstration in cell culture. Proc NatI Acad Sci USA 71: 84-88

21. Issekutz B, Borkow I (1973) Effect of glucagon and glucose load on glucose kinetics, plasma FFA, and insulin in dogs treated with methylprednisolone. Metabolism 22: 39-49

22. Issekutz B, Issekutz TB, Elahi D (1974) Effect of mannoheptulose on glucose kinetics in normal and gluco-corticoid treated dogs. Life Sci 15: 635-643

23. Olefsky JM, Kimmerling G (1976) Effects of glucocorticoids on carbohydrate metabolism. Am J Med Sci 271: 202-210

24. West KM (1959) Response of the blood glucose to glucocorticoids in man: Determination of the hyperglycaemic potencies of glucocorticoids. Diabetes 8: 22-28

Received: 16 July 1980

and in revised form: 26 February 1981

Dr. J. M. Olefsky

University of Colorado Health Sciences Center

Department of Medicine (B151)

4200 East Ninth Avenue

Denver, CO 80262, USA 